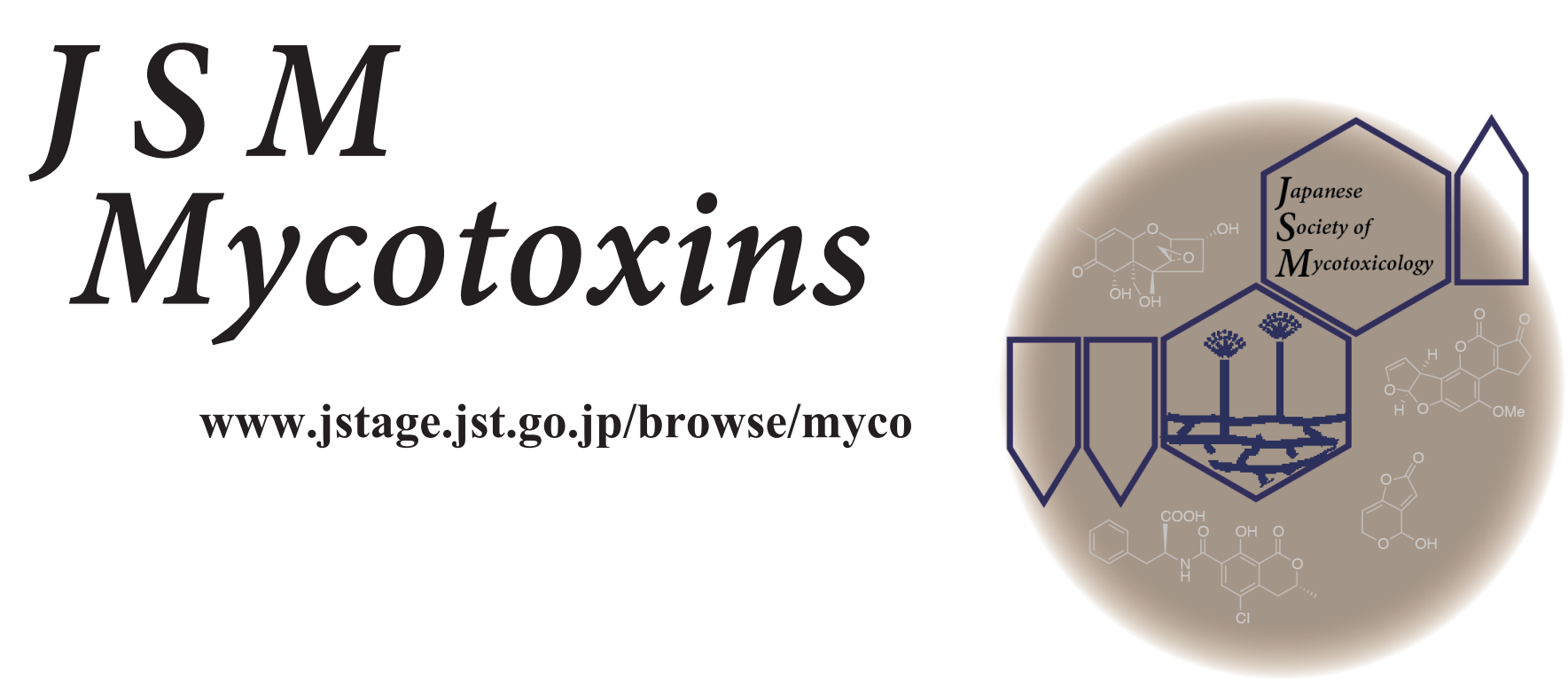

\title{
Report of the International Conference of Mycotoxicology (ICM 2018)
}

Hiroyuki Nakagawa

JSM Mycotoxins, 68(2):105-110 (2018)

http://doi.org/10.2520/myco.68-2-6

JSM Mycotoxins is issued twice a year, one volume a year, by the Japanese Society of Mycotoxicology and the purpose of the journal is to publish results and technical information regarding mycotoxins. JSM Mycotoxins publishes Reviews, original results (Research Papers, Technical Notes, Notes, and Letters), Proceedings of special lectures, symposia, and workshops of the meeting of Japanese Society of Mycotoxicology 


\title{
国際カビ毒会議International Conference of Mycotoxicology （ICM 2018）に参加して
}

\author{
中川博之 ${ }^{1,2}$
}

\author{
'国立研究開発法人農業・食品産業技術総合研究機構 食品研究部門 食品安全研究領域 \\ （=305-8642 茨城県つくば市観音台2-1-12） \\ 2 国立研究開発法人農業・食品産業技術総合研究機構 高度解析センター \\ （テ305-8642＼cjkstart茨城県つくば市観音台2-1-12）
}

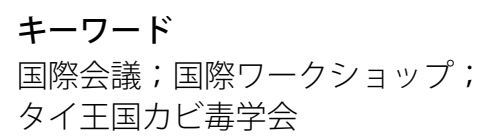

\section{連絡先}

中川博之，国立研究開発法人農業・ 食品産業技術総合研究機構 食品研 究部門 食品安全研究領域，

干 305-8642 茨城県つくば市観音 台 2-1-12

電子メール : hironkgw@affrc.go.jp

（2018年7月13日受領）

\section{要旨}

2018年2月14日，15日の2日間，バンコク（タイ王国）・カセサート 大学にてカビ毒国際会議International Conference of Mycotoxicology (ICM 2018)が「Driving Mycotoxin Research toward Global Food Security (グロー バルな食品安全へ向けての力ビ毒研究の推進）」のテーマの下，開催さ れた. 主催者であるタイ王国力ビ毒学会 (Association of Mycotoxicology, Thailand（AMT））の会長（Amnart Poapolathep氏）より，筆者が招待講 演を依頼され，「LC-MSによるフザリウム属菌産生カビ毒の分析」につい て講演を行った. 本会議には世界各国の力ビ毒研究者を含む約 230 人が 参加し，18件の口頭発表と13件のポスター発表が行われた. その概要 を報告する.

\section{学会の内容}

タイ王国では 2016 年 2 月 17 日 (水) 18日（木）の 日程でカセサート大学の獣医学部・薬理学科の 主催でカビ毒分析に関する国際ワークショップ International workshop on "Updated Techniques for Mycotoxin Detection in Animal Feed” がバンコ クで開催された。当時本学会からは高橋前会長が出 席された。これをきっかけにタイ国内でのカビ毒研 究推進の機運が高まり，2016年5月にタイ王国カビ 毒学会 (Association of Mycotoxicology, Thailand $(\mathrm{AMT}))$ が設立され, 初代会長にカセサート大学獣 医学部・薬理学科准教授の Amnart Poapolathep博 士が就任した。翌年1月10日 (火)にAMTとカセサー 卜大学の合同企画で, カビ毒国際会議International Conference of Mycotoxicology (ICM 2017) が "Understanding and Mastering Mycotoxins for Better Life” のテーマの下, バンコクで開催された. 当時本学会からは熊谷元会長が出席された. 本大会 はICMとしては2回目であり, 2018年2月14日（水） 〜15日（木）の日程でバンコクで開催された。 今回, Poapolathep氏より筆者が演者として招待を受けた ので参加した，その概要を紹介する。
カビ毒国際会議 International Conference of Mycotoxicology（ICM 2018）が, 夕イ王国カビ毒 学会とカセサート大学獣医学部・薬理学科の合同企 画で “Driving Mycotoxin Research toward Global Food Security”（グローバルな食品安全へ向けての カビ毒研究の推進) のテーマの下, 開催された（写 真 $1 \sim 3)$.

本国際会議では筆者（日本）のほか, アメリカ $(2$ 名),イタリア (2名), チェコ（1名），中国（1名）, タイ（2名）から招待演者が口頭発表を行った。若 手研究者の発表セッション (Young Researcher Session）もあり，先に日本マイコトキシン学会が 開催したISMYCO2016を彷彿させるような構成で あった（掲載の学会プログラム参照）。

海外からの参加者として上記招待演者以外で目 に留まったのは協賛企業のスタッフ程度であった が，小規模ながら国際色豊かであった。タイ国内か らの参加者も多かった模様で, 主催者側の発表で参 加人数は約 230 人とのことであった。 ポスター発表 の数は国際会議としては少なく 13 件で, メーカー関 係者 (Romer, Eurofin, Tecna, R-biopharm) の ポスターを合わせると 20 件ほど貼られていた。筆者 
は当初は自身の口頭発表（質疑時間込みで25分）の 担当のみのつもりで参加したが，会場に着くとこれ 以外に座長, ポスター発表の審査員（13件の学術的 発表のポスターから優秀賞を選ぶ：原則発表者から 直接説明を 3 分間程度で聞いて，質疑をした上で各 発表者に点数をつける) も依頼された。招待された だけのことはあり，任務が盛りだくさんであった。

筆者は,「LC-MSによるフザリウム属菌産生カビ 毒の分析」というタイトルで講演を行い, 主にLCMS/MSによるトリコテセン・ゼアラレノンの一斉 分析法 (+妥当性確認) と, 精密質量分析装置を用 いたモディファイドマイコトキシンの検出に関す る研究の成果を紹介した. 抽出試料量 $(10 \mathrm{~g})$ の適 切性（カビ毒污染のばらつきを考慮するともっと多 くするべきではないか）に関する質問や, カビ毒配

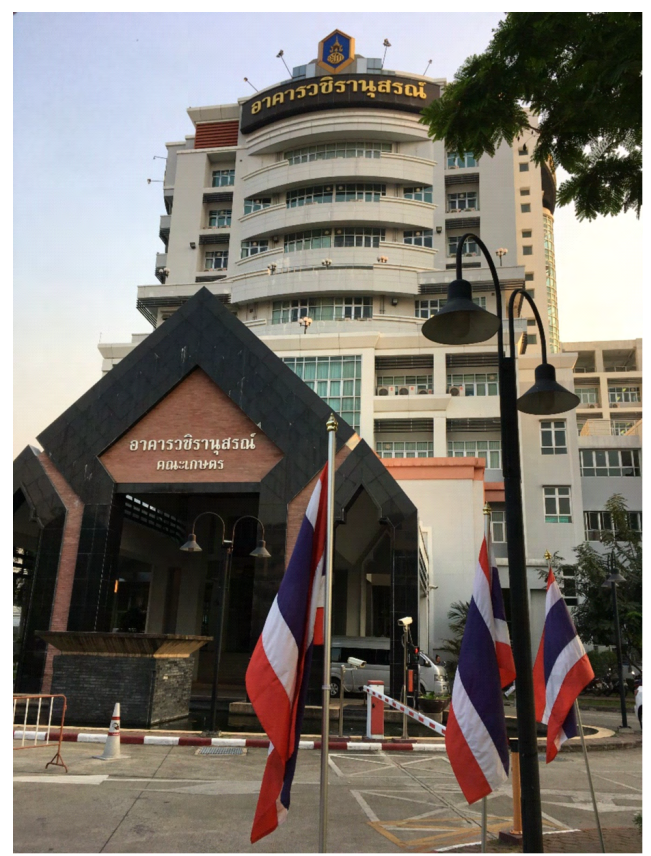

写真 1 会場となったカセサート大学農学部 Vajiranusorn棟

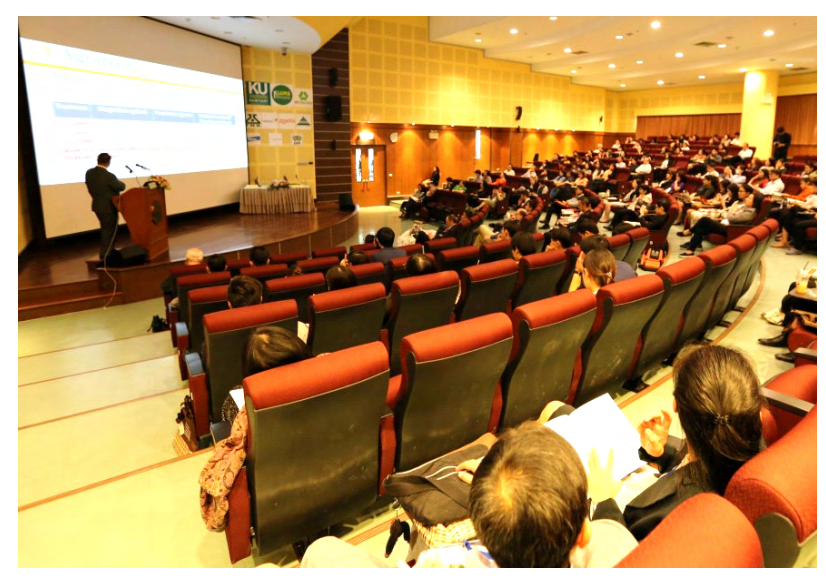

写真3 講演会場の様子
糖体（モデイファイドマイコトキシン）はすべての カビ毒について植物が作るのか, 等の複数の質問を 受けた.コンケーン大学で麦角アルカロイドの研究 を精力的に行っているJowaman Khajarern博士 は, 麦角が飛び出している植物体や麦角アルカロイ ドの中毒症状が出たと思われる動物等の写真を発 表のスライドに多数出されていて興味深かった.

ワークショップは2/15に開催された。資料 (下記) は英語で概ね作成されていたが，講演や実演の説明 の大半は夕イ語で行われた. 前半に複数の講師によ る分析技術や各種カビ毒の説明が行われ（写真4）, 後半は3班に別れてELISAキット，イムノアフィニ ティーカラム, QuEChers法ついて, それぞれの操 作を体験する内容になっていた。

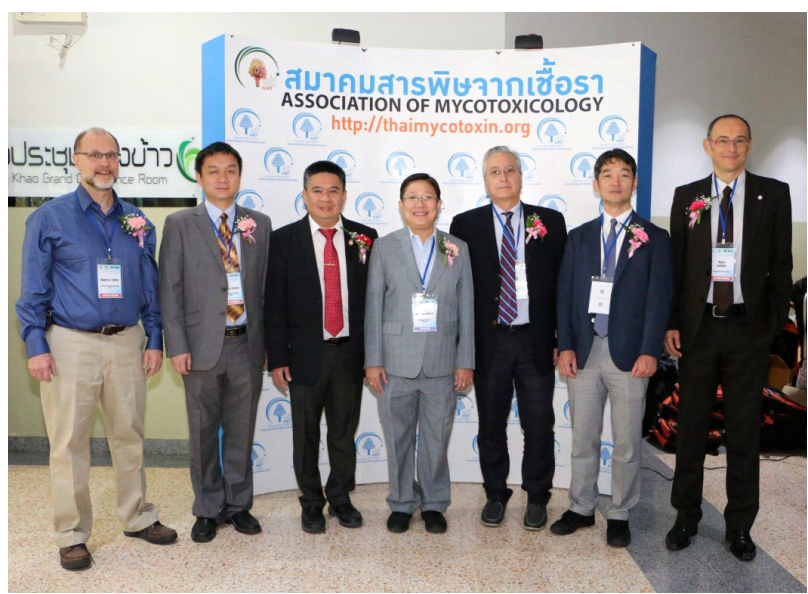

写真2 主催者, 演者の先生たちと会場ホールにて 左より，

Daniel D. Snow氏（米国），Zhaowei Zhang氏（中国）， Amnart Poapolathep氏 (タイ)，カセサート大学獣医学部 薬理学科長 Kanjana Imslip氏（タイ），Antonio Logrieco氏 (イタリア)，筆者，Mario Giorgi氏（イタリア）

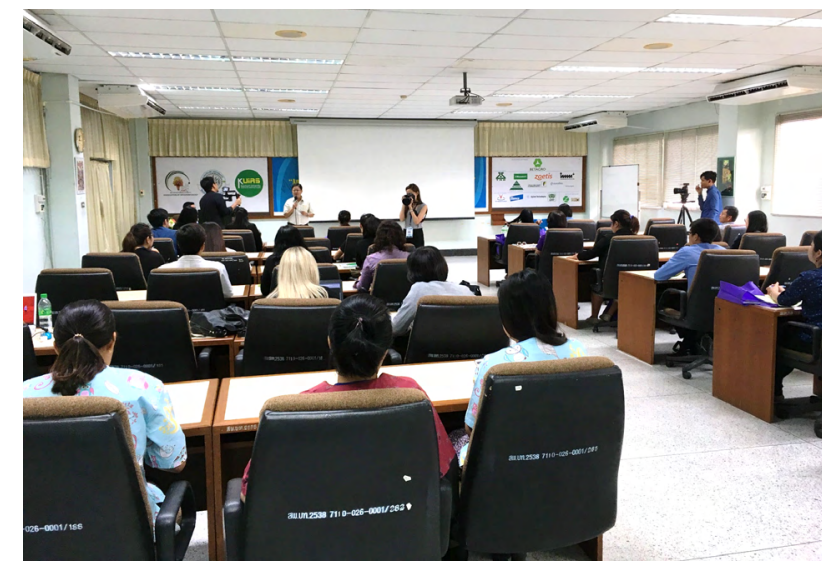

写真4 ワークショップの様子 


\section{THE FINAL SCIENTIFIC PROGRAMME}

International Conference of Mycotoxicology and Workshop (ICM 2018)

the $2^{\text {nd }}$ Annual Meeting of The Association of Mycotoxicology, Thailand

Theme: "DrivingMycotoxin Research Toward Global Food Security"

Organized by.... The Association of Mycotoxicology, Thailand

Department of Pharmacology, Faculty of Veterinary Medicine,

Kasetsart University, Bangkok, THAILAND, 14 ${ }^{\text {th }}$ February, 2018

Venue : Ruang Khao Grand Conference Hall, Vajiranusorn Building, Faculty of Agriculture, Kasetsart University, Bangkok, Thailand

Chair: Assoc.Prof.Dr. Amnart POAPOLATHEP

\begin{tabular}{|c|c|}
\hline Time & Language: English \\
\hline $7: 30-8: 45$ & Registration \\
\hline $\begin{array}{l}8: 45-9: 00 \\
9: 00-9: 10\end{array}$ & $\begin{array}{l}\text { Opening Ceremony by Dr. Chongrak WACHRINRAT } \\
\text { Acting President, Kasetsart University, Bangkok, Thailand } \\
\text { Welcome Address by Assoc. Prof. Dr. Amnart POAPOLATHEP } \\
\text { President, The Association of Mycotoxicology, Thailand }\end{array}$ \\
\hline $9: 35-10: 00$ & $\begin{array}{l}\text { Integrated an Innovative MYCOKEY Actions for Mycotoxin Management } \\
\text { in The Food and Feed Chain } \\
\text { Professor Dr. Antonio F. LOGRIECO } \\
\text { Research National Council, ISPA, Bari, Italy } \\
\text { Detection and Occurrence of Fusarium Mycotoxins in } \\
\text { The Agricultural Environment } \\
\text { Professor Dr. Daniel D. SNOW } \\
\text { School of Natural Resources, University of Nebraska-Lincoln, U.S.A. } \\
\text { Analysis of Fusarium Mycotoxins by Liquid Chromatography- } \\
\text { Mass Spectrometry (LC-MS) } \\
\text { Dr. Hiroyuki NAKAGAWA } \\
\text { Food Research Institute, National Agriculture and Food Research Organization } \\
\text { (NARO), JAPAN }\end{array}$ \\
\hline $10: 25-10: 40$ & Coffee Break \\
\hline $10: 40-11: 05$ & $\begin{array}{c}\text { The Importance of The Method Validation in Mycotoxin Detection } \\
\text { Professor Dr. Mario GIORGI } \\
\text { Department of Veterinary Science, University of Pisa, Italy }\end{array}$ \\
\hline 11:05-11:30 & $\begin{array}{l}\text { Can Bacteria Conquer Mycotoxin Challenges in Domestic Farm Animals? } \\
\qquad \text { Professor John A. DOERR } \\
\text { Department of Animal and Avian Sciences, University of Maryland, U.S.A. } \\
\text { Multiple Mycotoxin Determination and Control in Agro-Food and Feed } \\
\text { Professor Dr. Zhaowei ZHANG } \\
\text { Oil Crops Research Institute, Key Lab of Detection for Mycotoxins, CAAS, China }\end{array}$ \\
\hline $11: 55-12: 10$ & GROUP PHOTOGRAPHY (Altogether) \\
\hline $12: 10-13: 00$ & LUNCH \\
\hline $13: 00-13: 30$ & POSTER SESSION \\
\hline 13:30-13:55 & $\begin{array}{l}\text { Ergot Chronic Toxicity in Animals and Estimating Ergot Sclerote in Grain } \\
\text { Associate Professor Dr.Jowaman KHAJARERN } \\
\text { Faculty of Agriculture, KhonKaenUniversity, KhonKaen, Thailand }\end{array}$ \\
\hline $13: 55-14: 20$ & $\begin{array}{l}\text { Biocontrol Potential of Yeasts and Lactic Acid Bacteria Against Growth and } \\
\text { Aflatoxin Production of Aspergillus flavus in Corn Silage } \\
\text { Assistant Professor Dr.Cheewanun Dachoupakan SIRISOMBOON } \\
\text { Faculty of Sciences, Chulalongkorn University, Bangkok, Thailand }\end{array}$ \\
\hline $14: 20-14: 45$ & $\begin{array}{c}\text { Current Challenges in Mycotoxin Analysis } \\
\text { Professor Dr. Jana HAJSLOVA } \\
\text { Faculty of Food and Biochemical Technology, University of Chemistry } \\
\text { and Technology, Czech Republic }\end{array}$ \\
\hline
\end{tabular}




\begin{tabular}{|c|c|}
\hline Time & Language: English \\
\hline $14: 45-15: 00$ & Coffee Break \\
\hline \multicolumn{2}{|c|}{ Young Scientist Session } \\
\hline \multirow[t]{2}{*}{$15: 00-15: 10$} & $\begin{array}{c}\text { Individual and Combined Cytotoxicity of Major Type B Trichothecenes } \\
\text { on Jurkat T Cells }\end{array}$ \\
\hline & $\begin{array}{c}\text { Dr. Sawinee AUPANAN } \\
\text { Department of Pharmacology, Faculty of Veterinary Medicine, } \\
\text { Kasetsart University, Bangkok, Thailand }\end{array}$ \\
\hline \multirow[t]{2}{*}{$15: 10-15: 20$} & $\begin{array}{l}\text { A Preliminary Survey of Mycotoxins Contamination and Toxigenic Fungi in } \\
\text { Glutinous Rice in Cambodia, Laos and Thailand }\end{array}$ \\
\hline & $\begin{array}{l}\text { Thanapoom MANEEBOON } \\
\text { Kasetsart University Research and Development Institute, } \\
\text { Kasetsart University, Bangkok, Thailand }\end{array}$ \\
\hline \multirow[t]{3}{*}{$15: 20-15: 30$} & $\begin{array}{l}\text { Occurrence of Multi-Mycotoxin Residues in Rice and Barley } \\
\text { Using Multi-Class Analysis }\end{array}$ \\
\hline & Piyaluk SINPHITHAKKUL and Meythawe PONGPRAKET \\
\hline & $\begin{array}{c}\text { Department of Pharmacology, Faculty of Veterinary Medicine, } \\
\text { Kasetsart University, Bangkok, Thailand }\end{array}$ \\
\hline \multirow[t]{2}{*}{$15: 30-15: 40$} & $\begin{array}{l}\text { Factor Associated with Mold and Aflatoxin Contamination in by-Product } \\
\text { from Corn-Factory Using for Dairy Cow Feed }\end{array}$ \\
\hline & $\begin{array}{c}\text { Apussara SAEDAN } \\
\text { Faculty of Veterinary Medicine, Chiang Mai University, Chiang Mai, Thailand }\end{array}$ \\
\hline \multirow[t]{2}{*}{$15: 40-15: 50$} & $\begin{array}{l}\text { Fates of Fusarenon- } X \text { and Its Metabolite Nivalenol in The Goat } \\
\text { Wanchalerm PHRUEKSAWAN }\end{array}$ \\
\hline & $\begin{array}{c}\text { Department of Pharmacology, Faculty of Veterinary Medicine, } \\
\text { Kasetsart University, Bangkok, Thailand }\end{array}$ \\
\hline \multirow[t]{2}{*}{$15: 50-16.00$} & $\begin{array}{c}\text { Screening of Volatile Organic Compound-Producing Yeasts } \\
\text { Against Aflatoxin-Producing Fungi }\end{array}$ \\
\hline & $\begin{array}{c}\text { Sopin JAIBANGYANG } \\
\text { Department of Biotechnology, Faculty of Engineering and Industrial Technology, } \\
\text { SilpakornUniversity, NakhonPathom, Thailand }\end{array}$ \\
\hline \multicolumn{2}{|c|}{ Private Sector Innovation } \\
\hline \multirow[t]{2}{*}{$16: 00-16: 20$} & $\begin{array}{l}\text { Comparison of Commercially Available Multi-Mycotoxin } \\
\text { Immunoaffinity Columns with Direct Injection }\end{array}$ \\
\hline & $\begin{array}{l}\text { Dr. Claire MILLIGAN } \\
\quad \text { R-Biopharm-AG }\end{array}$ \\
\hline \multirow[t]{3}{*}{$16: 20-16: 40$} & $\begin{array}{l}\text { Romer Labs Multi Toxin Solution: Transition Methods of Mycotoxin } \\
\text { Analysis to New Method Development, Validation and }\end{array}$ \\
\hline & $\begin{array}{c}\text { Implementation of LC-MS/MS in Mycotoxin } \\
\text { Dr. Mabel NG }\end{array}$ \\
\hline & Romer, Singapore \\
\hline \multirow[t]{2}{*}{$16: 40-17: 00$} & $\begin{array}{l}\text { Cartridge ELISA for Mycotoxins } \\
\text { Dr. Maurizio PALEOLOGO }\end{array}$ \\
\hline & Eurofin Technologies \\
\hline \multirow[t]{2}{*}{$17: 00-17: 15$} & $\begin{array}{c}\text { The } 2^{\text {nd }} \text { Annual Meeting of The Association of Mycotoxicology, Thailand } \\
\text { Associate Professor Dr. Amnart POAPOLATHEP }\end{array}$ \\
\hline & President, The Association of Mycotoxicology, Thailand \\
\hline $17: 15-17: 35$ & Conference Conclusion \\
\hline \multirow[t]{2}{*}{$17: 35-18: 00$} & $\begin{array}{c}\text { Closing Ceremony } \\
\text { Assistant Professor Dr. Kanjana IMSILP }\end{array}$ \\
\hline & $\begin{array}{l}\text { Head, Department of Pharmacology, Faculty of Veterinary Medicine, Kasetsart } \\
\text { University, Bangkok, Thailand }\end{array}$ \\
\hline $18: 00-19: 45$ & Welcome Cocktail Party \\
\hline
\end{tabular}




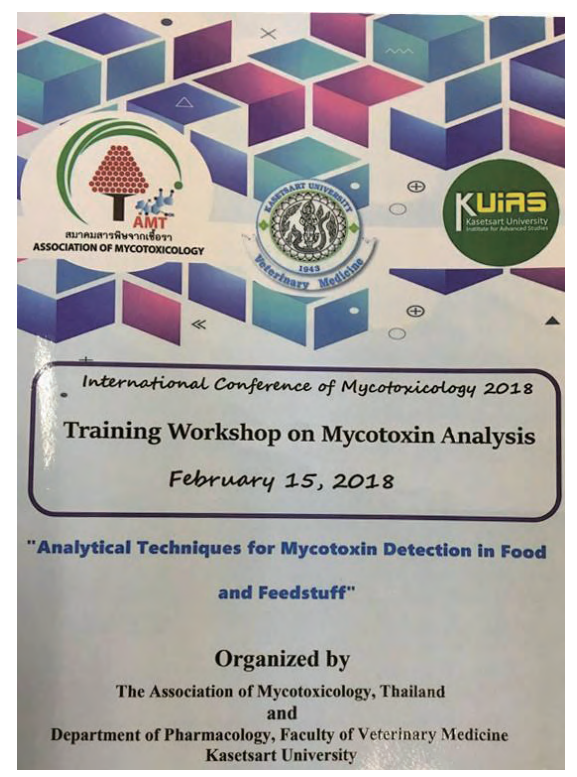

Overview: Updated techniques for mycotoxin detection

Assoc. Prof. Dr. Amnart POAPOLATHEP

ELISA technique for mycotoxin detection

Assoc. Prof. Dr. Usmuma JERMNAK

QuEChERS as a sample preparation technique for mycotoxin detection (LC-MS/MS)

Assoc. Prof. Dr. Phanwimol TANHAN

Immunoaffinity column (IAC) as a sample preparation technique for mycotoxin

Assoc. Prof. Dr. Amnart POAPOLATHEP

Analytical Method Validation

Assoc. Prof. Dr. Amnart POAPOLATHEP/ Assoc. Prof. Dr. Saranya POAPOLATHEP
所感

一番驚いたのは, タイでこの規模の国際会議 (ICM 2017, 2018) とワークショップ (2016, 2017, 2018）を毎年開催していることである. 財源確保も 容易ではないと思われるが, 実行するスタッフの労 力も相当なもののはずである. 日本マイコトキシン 学会が2016年にISMYCOを東京で開催したが，こ の実現までに 2003 年の香川大会から 10 年以上時間 がかかったことを考えると, 夕イ王国カビ毒学会 (AMT) の実力には頭が下がる思いである. Poapolathep会長の話によると, 今後も国際会議 （ICM）は毎年開催したいが，日本マイコトキシン 学会 (JSM) や中国とも連携してアジアMycotoxin societyのようなネットワークを作りたいので，ぜ ひ協力してほしいとのことであった. Poapolathep 氏奥様であるSaranya氏（ISMYCO2016では口頭
発表も担当）や，作田会長ラボ（東大時代）で学位 をとられたUsmuma Jermnak氏（ワークショップ では講師も担当）も扮元気そうであった。

イタリアのAntonio Logrieco氏から, Mycokey プロジェクト関連の国際会議が5月にフィンランド (Integrated preventive actions to avoid mycotoxins in malting and brewing, 5月23-24日, 2018, Helsinki，既に終了），9月に中国（2nd Mycokey International Conference - Integrated Solutions for Mycotoxin Management，9月16-18日，2018， Wuhan）で開催される (https://sciforum.net/ conference/2nd\%20Mycokey）とのことである。ま た，2019年6-7月頃にMycokeyの最終回の国際会議 をイタリア（Bari）で開催予定なので，ぜひ参加し ほしいとのことであった。 


\section{Report of the International Conference of Mycotoxicology (ICM 2018)}

\section{Hiroyuki Nakagawa}

National Agriculture and Food Research Organization (NARO), Food Research Institute, 2-1-12 Kannon-dai, Tsukuba-shi, Ibaraki 305-8642, Japan

Advanced Analysis Center, National Agriculture and Food Research Organization, 2-1-12 Kannondai, Tsukuba, Ibaraki 305-8642, Japan

International Conference of Mycotoxicology (ICM 2018) was held from Feb 14 th to 15 th, 2018, at Kasetsart University, Bangkok, Thailand. The conference theme was "Driving Mycotoxin Research Toward Global Food Security”. Approximately 230 people participated to this conference, and 18 lectures and 13 scientific posters were presented throughout the program. The author was invited by Dr. Amnart Poapolathep, the organizer, to deliver the lecture 'Analysis of Fusarium mycotoxins by liquid chromatography-mass spectrometry (LCMS''. This report briefly shows the contents of this conferences.

Keywords: Association of Mycotoxicology, Thailand (AMT); International conference; International workshop 